\title{
Teachers' Emotion and Identity Work During a Pandemic
}

\author{
Alexis L. Jones ${ }^{1 *}$ and Meghan A. Kessler ${ }^{2}$ \\ ${ }^{1}$ Department of Teaching, Learning, and Foundations, Eastern Illinois University, Charleston, IL, United States, ${ }^{2}$ Department \\ of Teacher Education, University of Illinois at Springfield, Springfield, IL, United States
}

This piece is a conceptual analysis of the care involved on the part of teachers during the COVID-19 era and the relationship it has to teachers' identities. Using the authors' stories, we address how fatiguing care is on a normal day, not to mention what is involved during the COVID era. This care, and the emotions involved, is closely tied to teachers' identities, calling into question how teachers conceptualize their teacherhood during a pandemic. Our hope is that others will consider where they may have misunderstood teachers' work. We aim to raise awareness of the complexity of teaching and suggest how teacher education can address and support teachers' needs.

Keywords: relationships, care, identity, teacher education, emotion

\section{OPEN ACCESS}

Edited by:

Leslie Michel Gauna,

University of Houston-Clear Lake,

United States

Reviewed by:

Michael Dubnewick, University of Regina, Canada

Nathalie Sandra Reid,

University of Regina, Canada

*Correspondence:

Alexis L. Jones

aljones16@eiu.edu

Specialty section:

This article was submitted to

Teacher Education,

a section of the journal

Frontiers in Education

Received: 15 July 2020 Accepted: 17 September 2020 Published: 09 November 2020

Citation:

Jones AL and Kessler MA (2020) Teachers' Emotion and Identity Work

During a Pandemic.

Front. Educ. 5:583775.

doi: 10.3389/feduc.2020.583775
"March 2020 will forever be known in the education community as the month when almost all the world's schools shut their doors" (Winthrop, 2020, para. 1). In response to the COVID-19 school closings, teachers all over were required to shift gears immediately to respond to students' and families' needs with synchronous and asynchronous virtual instruction. Teachers literally responded overnight to teach in new modalities. They have filmed themselves conducting experiments, hosted Zoom show-and-tell with Kindergarteners, prepared materials for students with variable Internet access, and even demonstrated concepts outside students' screen doors. There is no question that teachers of all grade levels, content areas, and in all sectors of education (i.e., public or private) are capable of incredible things. They have truly risen to this occasion.

Some teachers reported being busier than they were before the school buildings closed, as they were expected to be present and available, with office hours during lunch, and student groups arriving and leaving throughout the day. All of this took place while trying to simultaneously instruct their own children who were home (Strauss, 2020). Still others described attempts to track down the students they stopped hearing from (Sawchuck and Samuels, 2020). Understandably, teachers had significant concerns about these students. Schools can provide a predictable routine and a safe space for students, and when that goes away, "I'm calling and emailing them constantly," said a teacher in New York. "Maybe their parents are sick, undocumented or out of work. Some might not have a Chromebook or internet. They are literally MIA and may never come back" (Willen, 2020, para. 2).

Over the last several months, the COVID-19 pandemic has caused the nation's teachers to enter into a shocking, and at many times painful, natural experiment. Despite a slow march of policies and cultural practices that have chipped away at the professional status of teachers (Milner, 2013) and the resources they need to do their jobs, the sudden closure of the nation's schools has brought into sharp focus the true importance of teachers and the work most do every day on behalf of other people's children. However, this is not the first time many of the nation's teachers have found the capacity to do great things for and with students, families, and communities despite sparse resources and a pervasive lack of respect. In fact, as a result of COVID-19, we may be seeing the intensification of the professional marginalization that teachers have faced for decades. 
Teacher education is at a crossroads. Rather than "doubling down" on the traditional pressures imposed on teachers and the profession, this could be an opportunity to consider a new path. It is time now to take a step back and reassess how mounting pressures have not attended to teachers' humanity. As teacher educators ourselves and with a nod to Nel Noddings, we would like to raise a critical question in this time: Who will care about and for the teachers?

This piece is a conceptual analysis of the care involved on the part of teachers during the COVID-19 era and the relationship it has to teachers' identities. The authors tell personal and composite stories of their COVID-19 professional and personal experiences, hoping that these narrative snippets will highlight the current clash between teachers' "out-of-classroom" and "inclassroom" experiences (Clandinin and Connelly, 1996). We address how care, while at the heart of all teaching, can be truly exhausting on a normal day. Added to this fatigue, teachers now work from home in front of their laptops, chart paper taped to the refrigerator behind them, their own families needing their time and attention. The point of this piece is to help others understand where legislators, community members, and even families may have misunderstood teachers' work. Our ultimate goal is to raise awareness of the complexity of teaching and to suggest how teacher education can address and support teachers' needs.

\section{EMOTIONS AND CARE ETHICS}

Nias (1996), a prolific author in the areas of the moral nature of teaching, teacher identities and relationships, and care in schools, wrote about "intrusions" into their professional territories:

\begin{abstract}
Far more intense was teachers' and headteachers' reaction to what they saw as "intrusions" into their physical or professional territories... Golby [Michael Golby, as in "Teachers Emotions, An Illustrated Discussion" (1996)] asked two experienced, committed women teachers in English schools, one primary, one secondary, direct questions about their emotional reactions to school life. The major source of their affective satisfaction and emotional security was what Golby describes as "the intimacy of teaching children." Problems arose when other people-colleagues, parents, OFSTED inspectors-breached, or threatened, the tight boundaries that they had drawn around this central area of their work. Then they felt anxious, impatient, distressed, depressed and angry (Nias, 1996, para. 26).
\end{abstract}

With the above quote in mind, we can begin to talk about the intense emotions felt by many teachers when it comes to the care they have for their students. Emotion, described by Koestler (1967) as, "mental states accompanied by intense feeling and (which involve) bodily changes of a widespread character" ( $p$. 835 ) is a strong facet of teacher education literature. Keck (2019) described a reflective teacher as one who is "vulnerable and motivated by forces not entirely conscious or rational" (p. 1). Teaching on any day can be difficult and involves all of the teacher-their physical body, mind, and heart (Nias, 1996).

The global pandemic we face in 2020 has caused a huge intrusion into the special relationship between teachers and their students. Clandinin and Connelly (1996) described the "out-ofclassroom" (e.g., policies, research, senior administration) and "in-classroom" (e.g., interactions with students, collaborative relationships) spaces in education. It is difficult to remember a time when the out-of-classroom space has ever intruded more on the in-classroom space. Teaching is an interaction (Jones, 2017), and COVID-19 has severely diminished this interaction; for example, students with limited internet access were not able to see one another on Zoom like many others, depersonalizing the "classroom" environment. While teaching was already a difficult, complex profession, COVID-19 has pushed aside some of the heartwarming, relational positives for teaching and replaced them with stress, increased demands, and worry about student safety.

\section{WHAT DOES IT MEAN TO CARE?}

Caring, kindness, and emotionality are necessary parts of teachers' work. This is both a choice and also part of a teacher's professional identity:

Whilst this choice led them to sometimes "get exhausted and think about certain kids all night"... or be perceived in a disempowering way...all teachers in this study saw the caring work they were engaged in as being an integral part of their professional identity (O'Connor, 2008, p. 121).

O'Connor described caring as the emotions, actions, and reflection involved as teachers help their students in a variety of ways. While caring appears to O'Connor to be an action-we care for and about one another by completing caring actions-possibly the most prolific author on the ethic of care (Noddings, 1984, 2013) describes care as a relation. Caring is not to be considered a set of rules or actions, it is "a response to individuals with whom one is in relation" (1984, p. 497). We do not care because of our duty, we care through our attempts to institute and maintain a caring relationship. Though there is a "carer" and a "cared for," these categories are not fixed. Caine et al. (2020) move even beyond this ethic of care, and "note this shift from an ethics of care to include a relational ethics [italics added] in the shift to a 'becoming together' with responsibility to and for each other' ( $\mathrm{p}$. 272). The ethic of care is the solid foundation, but the relational ethic is how pairings consider less who is in the role of carer or cared for, and more about entering a transitional space where both parties attend to one another and their co-created space.

Noddings (2013) shared a story of a fictional young man responsible for the care of his mother. If this young man transfers his mother's care to a nursing facility, does he still care for her? What if he does not visit or call, but he pays the bills? What if he worries about her frequently? What if his mother experiences his acts as caring? Noddings stated that as opposed to depending on rules, as the ones who care for others, we can only decide what is and is not care if we receive confirmation from the cared-for. "Although I can never accomplish it entirely, I try to apprehend the reality of the other" (p. 14): We notice another person's need or their pain and are called upon to do something. We try to consider the reality of the other person and eliminate what is intolerable. When an individual has noticed, 
considered, reflected, and kept the relationship at the forefront of their thoughts and feelings, they can be said to be in a caring relationship.

An example of Noddings's (2013) ethical and relational caring might look like this: A teacher education student is struggling with coursework as well as personal issues with her job and her boyfriend. She is up late either working or on the phone with him, which means she has little time left for the class readings and comes to class exhausted. She has begun falling asleep in class and her assignments are consistently late. Because the energy of the teacher in an ethical and caring relationship moves toward the student, the teacher in this case begins with the understanding that this student has the best of intentions; she wants to do well in class, but things are getting in her way. When preparing to have a conversation with this student, the teacher thinks less of the course content not being addressed in this student's life and more about the student and the student-teacher relationship. The conversation during office hours may begin with a general, "How are things going?" and move toward the more specific issue of missing work and mini-naps during class. "I know you want to do well in this class," "You have enormous potential as a teacher," and "How can I help you during this time?" are all parts of this caring conversation, designed to maintain the teacher-student relationship as well as move the student toward the best version of herself. The student must respond in some way that lets the teacher know that care has been received in some way; this may be a nod, a smile, or follow-up questions. "Teachers sometimes forget how dependent they are on the response of our students" (Noddings, 2012, pp. 772-3). The response of students (e.g., a smile, a nod, a furrowed brow, a laugh) is notably minimized or absent during remote instruction; if students make it to their virtual class meeting, attention and responses can be unfocused and diffuse. Alexis's son, for instance, has preferred to keep his Zoom camera off, so his teachers cannot see any of his non-verbal responses to instruction.

O'Connor (2008) described how exhausting teaching can be for those who make the choice to teach in a caring manner:

Being able to act as a professional and still sustain a sense of self within the [teaching] role has emotional implications for teachers, and [her research participant] made frequent comments about the level of "emotional energy and sheer adrenalin" which she felt she needed to maintain whilst teaching (p. 122).

Because good teachers naturally invest pieces of themselves in their work, their personal and professional identities are interrelated. The teacher quoted in the O'Connor snippet above described the need to separate her work from her personal life, something that in the COVID-19 era teachers have been increasingly unable to do.

\section{CARING DURING COVID-19}

Our news and social media feeds are filled with stories of the lengths some U.S. teachers will go to care for their students. When a student did not understand her mathematics, one teacher visited the student's house and explained it with a glass door in between them for safety. More than one teacher parade has gone through student neighborhoods, teachers honking their horns, signs draped on their cars, letting students know they were still with them in spirit though the school doors were closed (Krasinski, 2020). These are quite obviously the caring behaviors of teachers who want their students to understand the content and feel secure in their relationship.

However, it is difficult to have the conversation about emotions and care when students are missing from synchronous online classes, email exchanges, or physically distanced home visits. O'Connor (2008) is correct that these behaviors are ones teachers would do for children they care about, but whether or not the teachers are able to care for their students at this time is up for discussion. After all, Noddings $(1984,2013)$ conception of care is dependent on the relationship, and what relationship do students and teachers have when communication is minimized or even absent? Teaching turns into less of a negotiated partnership and becomes more of an "assignment," quite literally in lowinternet areas that require packets of printed work for students because synchronous online instruction is not feasible.

As well, while some teachers are demonstrating these caring actions for students in unique and superhuman ways, many of them also have caring relationships in their own households. Consider those teachers with children: If I displace my motivation toward my assigned students as Noddings (1984, 2013) would suggest, how am I able to also care for my own children in this manner? In Alexis's own experience as a teacher educator, she had this exact tension in play at her house between March and May 2020. At the same time her 5th grader came home with a variety of virtual learning experiences from which to choose, she was switching her face-to-face course to become virtual only, no small feat when she was previously preparing to send students into the K-5 schools for field experiences as opposed to continuing with direct instruction. Alexis, her son, and her husband made a family workplace at the dining room table so the adults could work while encouraging their son to complete reading, math, science, and social studies work online. Alexis's privilege at this time cannot be ignored; as difficult as it was to get research, writing, and teaching done while directing the learning of an 11 year old, she admits that in a two-parent household, she was able to "escape" to a room alone when thoughtful, quiet work was required. Their son received good grades and required no special services. Alexis's position was easier to transition to remote learning than a plumber, nurse, or Kindergarten teacher's job, so her salary was not affected.

However, who can Alexis and her husband be said to have cared for at this time? Both their son and their respective students? Our motivation can only be displaced toward the caredfor so much; at some point, someone we care for becomes ignored or temporarily put to the side. At times, this was Alexis's son; at other times, Alexis's students may not have received her full attention. She worried constantly about both. She received Noddings' confirming response from her son because they were constantly together; a few of her students kept in touch via email and she could see their faces during class instruction, but if students were not able to make it to synchronous classes or were not comfortable with technology, she rarely heard from them. 
Mentioned above, Noddings (1984, 2013) concept of confirmation is especially important to consider in the COVID19 era. How well are teachers able to apprehend their students' reality when they do not see them in person every day? In the horrible but very real instances of child abuse, can I as a child's teacher see what they are going through if I do not see their face or bruises on their arms? The authors of this article are not the first individuals to worry about instances of child abuse (Substance Abuse Mental Health Services Administration., 2020) increasing when mandated reporters and children are physically separated.

What if students' internet access is limited, and they never make it to my Zoom classroom? How can I receive that confirmation of care that completes Noddings' cycle of the caring relation? I cannot see them, I may not hear from them, and their instruction, packets of worksheets due to the area's limited internet, is essentially a shot in the dark toward addressing their instructional needs. The teacher's actions are truly caring: She is attempting to keep students engaged and learning something during a crisis, she is making concerted efforts to see students' faces on Zoom, Blackboard Collaborate, or Google Meet, she is sending notes home, driving by homes, etc. While O'Connor (2008) would certainly consider these actions caring ones, Noddings $(1984,2013)$ could disagree that this arrangement is an example of relational caring. Noddings' conception of care is not based in action, it is based on the negotiation of the relationship. It is based on a cycle of caring action, confirmation, negotiation, and reflection. It is more about the relationship than the intention or action.

\section{SUMMARY: TEACHERS' ABILITY TO CARE}

In summary, teachers' tendencies to care have not changed during the sharp transition from traditional schooling to pandemic schooling. Teachers still felt worry, frustration, overwhelm, and many other emotions during their planning and instructional efforts. However, if we consider care as a relation, where a caring teacher requires confirmation the care has been received and interpreted as such, COVID-19 has been a massive interruption. Since being a caring individual is a basic expectation of teachers, their identities are shaped by how well they see themselves caring for their students. What must be considered is whether the changes in teaching required by COVID-19 have made it more or less possible for teachers to care for their students; as a result, how has this impacted teachers' identities? If teachers are struggling with maintaining caring relations with students, how will this influence how they feel about themselves as teachers?

\section{TEACHER IDENTITY IN THE PANDEMIC}

Teachers' personal and professional lives have now been fully integrated in response to COVID-19 and the emergency transition to virtual learning. Teachers are now attempting to teach Common Core math over Zoom to a group of students and parents while simultaneously parenting their own children and caring for their homes and other loved ones. This mash-up of lives brings to light a reality that has always been present for teachers: the separation between the personal and professional self is somewhat of a fallacy. This is a lovely but messy and challenging reality for teachers, especially in the current context. The emotional challenges associated with this drastic change also relate to teacher identity. The following section will discuss the theoretical and empirical definitions of teacher identity that are relevant here and interrogate this research through composite examples from one of the authors.

\section{WHAT MAKES UP A TEACHER'S IDENTITY?}

The literature and theories of teacher identity are vast. However, the authors of this paper understand teacher identity as socially constructed and in interaction with varied discursive elements. Scholars have asserted that teacher identity is fluid and socially constructed and remains loosely defined due to the myriad of facets embedded within (Beijaard et al., 2004; Alsup, 2006; Rodgers and Scott, 2008; Beauchamp and Thomas, 2009; Akkerman and Meijer, 2011; Izadinia, 2013). Other research has found that teachers' identity work is implicated by perceived future events. New teachers, in particular, consider their possible selves when forming their identities within the domains of relationships, management, instruction, and professionalism (Hamman et al., 2010). These future selves are also imagined during conversations with mentors (Urzúa and Vásquez, 2008) and when new teachers reflect on past practice and plan for the future (Lutovac, 2020). Similarly, new teachers' reflections on past imaginations of what it may be like to become a teacher influence the shaping of contemporary teaching selves (Lortie, 1975).

Zembylas (2003), in particular, advocates for a poststructuralist conceptualization of identity that accounts for the ways in which identity work is felt, embodied, and discursively constructed. From this perspective, emotion is "inextricably" linked to identity, and emotional experiences are an important component of self-knowledge. Citing Haviland and Kahlbaugh (1993), who call emotions the "glue" of identity, Zembylas points out the role of emotion in helping individuals assert meaning to experience and identity. If one takes this discussion a bit further, a post-structuralist perspective would also explain the role of emotion in identity formation as something that is influenced by the discourses of power and knowledge that surround teachers.

In particular, Foucault (1979) argues that selves do not develop within a vacuum; they are implicated by exterior structures and regulatory forces. For teachers, these discourses include beliefs about what teachers are or are not, relations between teachers and students, and the function of schools in society. Indeed, teachers are situated within layered interpretations and demands about their work, which puts them in a position of constant negotiation and enactment. From this perspective, "identity formation is a by-product of power/knowledge within a context of normalized institutional codes" (Zembylas, 2003, p. 224), and teachers are compelled to construct their identities from the discursive materials that are made available to them. Teachers 
also construct identities through discursive acts, and their agency to do so is constituted of the knowledge and power that acts upon teachers (Foucault, 1979). To extend this point, Butler's (1999) discussion of performativity in the creation of gender identity can be applied to further elucidate the role of power in the construction of self. Butler asserts that gender is an element of identity that is stylized and performed; individuals are only able to work with the tools that are laid out for them by the regulatory influences present in their lives. In similar ways, the teacher self may be stylized and performed according to or in defiance of the normative definitions of the profession Therefore, teachers' identity work is done within a specific frame of possibility; "authority is attributed and installed ... the very expectation [of being] ends up producing the very phenomenon that it anticipates" (pp. xiv-xv). Although these are dense concepts to consider, they are helpful for interrogating the complexity of teachers' selves and realities during the COVID-19 pandemic.

To summarize, teacher identity is socially constructed (involving institutions, discourses, relationships), impacted by discourses of power and knowledge (communicating what teachers should be and should do), connected to and enacted via emotions (which communicate import), dynamic (in constant negotiation with aforementioned factors), and reflective yet forward-thinking. These elements of teacher identity are heavily implicated by the shifting sands of the COVID-19 pandemic.

\section{REMAKING TEACHER IDENTITY DURING A PANDEMIC}

Long before COVID-19 and widespread school closures, one could argue that there has existed a prevalent discourse about the key role of teachers to support the academic, social, and emotional well-being of students. Images and stories of well-loved, inspiring teachers permeate popular media, and school-wide intervention programs ask teachers to demonstrate evidence that they can construct learning environments and lessons that address the needs of the whole child. These messages become the stuff from which teachers construct their concepts of self, facilitating in many teachers an identity deeply rooted in providing the very care that was discussed in the previous sections of this paper.

As teachers work to construct their identities, they have no choice but to pick up the discursive tools that are available to them. Therefore, many teachers define their core motivation for becoming or remaining in the profession as the capacity to make a difference in the lives of children and help individuals achieve lifelong success. Teacher organizations like the National Education Association amplify such discourses in their mission statements, including ideas such as the role of schools to further democracy, equity, and justice (National Education Association (NEA), 2019). Even Meghan, one of the authors of this paper, wrote in her undergraduate teaching philosophy statement about the importance of attending to the "academic and personal needs of all students in and outside of the classroom." Although Meghan now understands the many political and social factors that complicate such work, it is still something she believes (to a certain extent) to be possible and discusses it with her preservice teachers. In this way this kind of commitment often results in teachers leveraging agency toward enactment of their commitments as a means of performing their identity daily. Yet, this agency can be complex.

Zembylas (2003) describes agency as the connection between identity and emotion. The enactment of emotions in the construction of teacher identity constitutes agency; yet Zembylas asserts that this connection is dependent on the "viability of teacher agency" (p. 224). Taken from a post-structuralist perspective, teacher agency is contingent upon the cultural, historical, and policy dynamics in which a teacher is situated. The viability of teacher agency impacts teachers' capacity to enact their commitments and, therefore, feel that their identities are being realized. This has certainly been severely impacted by COVID-19.

To illustrate, one may consider the tensions produced for a teacher when teacher agency compromised. In Meghan's teaching of preservice teachers after the outbreak of COVID-19, she experienced tension between her desire to attend to both the personal and professional needs of her preservice teachers. She instituted several new Zoom sessions and assignments, but these soon became difficult for her students to complete. It seemed that these two commitments were more at odds with each other than they had previously been due to the constraints of technology and the new personal challenges her students were facing. These tensions soon left Meghan feeling that she had less agency in enacting the kind of truly responsive instruction she had prior to the pandemic. Her colleagues in PK-12 settings likewise felt frustration and fear over the lack of face-to-face connection they were able to maintain with their students, which removed a core opportunity to realize their commitment to their students' academic and holistic needs. In the sudden need to adapt their view of work and self during the pandemic, Meghan and many of her PK-12 colleagues were left feeling uncertain and inadequate.

Although the influence of a global pandemic on teacher identity and agency has not yet been studied in its current iteration, prior research can provide some clues into the experiences that may be realized by many teachers. For instance, Connelly and Clandinin's (1999) collection of narrative explorations of teachers and schools offers particular insight into current tensions. They assert that teacher identity and practice is interwoven. So much so, that major reforms or changes in teaching expectations can cause a feeling of loss for teachers, necessitating changes in their "stories to live by," and resistance when changes are at odds with a teacher's efforts to maintain their constructed stories of teacher self. Further, Clandinin and Connelly conceptualize a teacher self can be conceptualized as a storied landscape (Clandinin and Connelly, 1996, 1998), something dynamic, interconnected, and influenced by the native and the foreign. The storied professional landscapes of teachers have often long been considered by scholars in relation to policy change or reform (e.g., Tyack and Cuban, 1995; Fullan, 2007). Taking a beautifully metaphorical approach, Craig (2002) conceptualizes the knowledge and powers that influence and shape on teachers' selves and work as conduits, pointing out that these represent "school districts, pouring twice 
and thrice-removed imperatives originating in the academy into schools, greatly shaping practitioners' work and attempting to impact student learning," or the "multiplicity of competing and conflicting forces trying to define educational reality through filtering information" (p. 199).

Clandinin and Connelly (1996) point out that while others may see teachers as simply resisting or subverting new knowledge or reform, teachers are instead reacting according to their narrative understandings of selves, schools, and students. To engage in true change means to shift how one knows their classrooms and professional selves. To take this apply this point to the changes being wrought by COVID-19, teachers are now dealing with a complete disruption of their storied professional landscape and, therefore, their sense of how they know themselves and their students. Formerly, "changes ripple[d] through the school and influence the whole web of stories" (p. 160), now the changes have come as something akin to a forest fire, requiring a full remaking of the landscape and teachers' stories of self.

More recently, researchers have found that reform and policy shifts create identity tensions for teachers, especially when highstakes accountability or testing is involved (Cross Francis et al., 2018), which can have implications on teachers' feelings of efficacy and commitment within the profession (Day et al., 2005). Take, for example, Ball's (2003) discussion of teacher performativity within the context of neoliberal education reform in England. Ball argued that teachers experienced contradictory values during the advent of high-stakes accountability policy. Testing and evaluation measures caused many teachers to set aside their personal values and investments (and therefore the cornerstones of their teaching identities) for the new accountability measures. Others remade themselves and their teaching according to the discourses of teacherhood and quality that were being enforced, either cynically or with resignation. Tensions were experienced by many teachers, and some engaged in resistance against those accountability requirements they felt were most at odds with their individual teaching values. In every case, the influence of power as a regulatory force was at work on many teachers, and as Ball put it, "New roles and subjectivities [were] produced as teachers [were] re-worked as producers/providers, educational entrepreneurs and managers [...] subject to regular appraisal and review and performance comparisons" (p. 218). Taking a more narrative approach, Craig (2001) illuminates the ways in which top-down school reforms can impact teachers' understanding of self, school, students, and statute. Teachers articulated the ways in which "stateinterpreted, national reform movement did not resonate with the current version of the story of school [they] had come to know... [and a] lack of fit between and among stories of school and stories of teachers" (p. 324). The language of reform carried implications for how teachers interacted with colleagues, how or whether they had assimilated the appropriate knowledge (as defined by the state-directed reform agency), and practices; all of which "bore consequences for their identities" (p. 325).

This remaking of teacher selves is similar to that which is taking place in the COVID-19 era. As this paper is being written, a tense and politicized debate over the reopening of schools is taking place. Teachers are therefore being put in a complicated position: to weigh the commitments associated with their identities as carers of other people's children against their commitments to care for themselves and their loved ones. For some teachers, this is an impossible decision. Local, state, and national policies or recommendations are in constant flux, creating uncertainty and instability for teachers who are attempting to negotiate the relative weight and import of each component of their identities.

Ruohotie-Lyhty's (2018) model of identity-agency further examines this process of negotiation. When teachers' identityagency work is characterized by tensions, a teacher may engage in defensiveness (protecting their identity through action) or renegotiation (reconsidering their identity in light of new demands). Depending on the contextual changes at hand, teachers may find themselves resisting or readjusting their identities. In either case, this work is emotionally taxing.

The tensions associated with this can also be discussed within the theoretical constructs of the aforementioned poststructuralist theory of teacher agency. If cultural and political discourses set the boundaries for what is possible, "teachers learn to internalize and enact roles and norms assigned to them by the school culture through what are considered 'appropriate' expressions and silences” (Zembylas, 2003, p. 225). Teachers' identities, and their agency to act within existing frames of possibility or appropriateness, are determined by the "discursive environments [that]... set the conditions of possibility" for those actions and identity work (Zembylas, 2003, p. 226). Furthermore, a teacher's identity is more than just the sum of their practices, interactions, and institutional expectations; identity-and the emotions therein embedded-is the enactment of a teacher's investments or feelings (Britzman, 1993).

Similarly, during the pandemic, the entire landscape of teachers' realities has shifted. Initially, this took place overnight, while public discourse continued to demand their accountability. While attempting to adapt her practices and materials for virtual teaching in March of 2020, a teacher's identity may have undergone one round of renegotiation, reconceptualizing her teaching values or commitments for a new modality. Take for example, an advanced placement teacher who leveraged strong relationships with students during history lessons. This teacher likely maintained a figurative (if not literal) map of each student's needs, and worked hard to address these needs through relational knowing and a caring environment (Noddings, 1984). This responsiveness was not only a means-to-an-end for getting through to students, but likely a core piece of how the teacher saw herself. Furthermore, the teacher balanced these concerns with an appreciation for the expectations of administrators and other stakeholders. Therefore, the teacher also took deliberate steps to become informed about trends in curriculum and practices in order to be an accountable steward of the community's most precious assets.

This teacher's conception of self would be challenged as she struggled to maintain relationships virtually during the school closures, even when only 30 percent of students were consistently engaging with online material. Meanwhile, this teacher was still 
under external pressure from administrators or family members to maintain "rigorous" instruction in line with the AP test. This teacher may be renegotiating whether relationships are indeed as integral to working with students. Or, to take the emotional element of identity into perspective, the teacher may be experiencing shame, feeling that they are powerless, personally inadequate (Batarky, 1990), or "lack these abilities or that their aims are not worthy" (Zembylas, 2003, p. 228) according to the dominant discourses of power influencing that teacher's context. Feelings of shame and doubt are documented in the literature as common in teachers' experiences and enactment of identity. In particular, teachers can feel shame when their own socioeconomic class and obligation to carry out hierarchical policies is at odds with the classed identities of their students (Van Galen, 2017). If not able to produce the academic gains some reformers associated with educational equity, teachers may feel that they have fallen short. Further, the work of conforming to social constructions of teacher "effectiveness" can breed shame or a sense of doubt in teachers (Edgington, 2016). Therefore, the tensions associated with reassessing and renegotiating elements of her teacher identity would be understandably taxing.

\section{SUMMARY: IDENTITIES FACING CONTINUOUS CHANGE}

Tensions like those described above are likely to continue to mount as the 2020-2021 school year is underway. While the lives of some teachers are literally on the line, economic and political arguments seem to barely acknowledge, if not completely ignore, this reality. Consider the likely impacts of a teacher's attempts to predict or prepare for the 20202021 school year with so much fear, uncertainty, and threat of shame hanging in the balance. The aforementioned domains embedded within teacher identity (relationships, management, pedagogy, and professionalism) are all impacted by the pandemic.

With the above theories and research in mind, consider the additional discursive (and emotionally relevant) elements that may influence a teacher's re-construction of identity in the era of COVID-19. It is not uncommon for teachers to center their sense of self and value within relationships with students ( $\mathrm{O}^{\prime}$ Connor, 2008). Safe interactions are only available by internet, and in many areas this internet access is unreliable; consequently, this identity may undergo a shift. Additionally, teachers' senses of self are also constructed within somewhat rigid policy and reform discourses that enforce technical-rational definitions of quality, enforcing the idea that a teacher's work and worth are tied to the outcomes they produce in student learning (Mockler, 2011). Therefore, a teacher's self post-pandemic will be a complex quilt, patching together concern for self, concern for one's teaching values or commitments, and concerns for one's community with little information about how things may look in the future.

Regardless of the time spent in the classroom prior to the pandemic, the foundational pieces of teachers' identities have been significantly altered, if not removed entirely, due to
COVID-19. Relationally centered instruction was moved online, hampering many teachers' capacities to each day realize their sense of self as mentor, helper, and nurturer of students. Yet, the parts of the teacher's identity that were attuned to accountability and stakeholder interests were still present, intensifying the pressure to uphold academic success.

\section{SIGNIFICANCE}

Many readers are aware of the time it takes to write and have an article accepted for publication. In the best of worlds, several months are involved (It can take over a year at times). While this piece can be considered the former as opposed to the latter example, the COVID-19 era has already changed so much for teachers that an additional article on this topic is needed. In March and April of 2020, much of the country appreciated the work of teachers because it had been outsourced to the home, and families who were unaware of the hard work involved in teaching playfully and desperately offered teachers increased salaries. By July 2020, however, the tone had changed. Repeated calls for children to go back to school came from the federal government and several state and local governments (Goldstein and Shapiro, 2020), with teachers' questions about their own safety and that of their students falling on deaf governmental ears.

So what? Why is it important to consider the emotions and caring involved in teachers' identities during a time like this? We would argue that calls for considering teaching a complex and difficult profession have never been needed more than they are during the COVID-19 era. The fact that families are finding it necessary to go back to work does not mean that teachers should provide the necessary childcare (Chiu, 2020; Meckler, 2020). Teachers are not the nation's babysitters. It is not incumbent upon them to care enough to provide not only childcare, but thorough, challenging instruction to EC12th graders at a time when they are quite literally putting their lives on the line. We would ask governmental bodies making these decisions, especially our Secretary of Education, how many teachers were involved in the decision to go back to school? Or are teachers (again) being asked to follow the decisions others have made without being included in the conversation?

It is also important to the authors to consider the implications of what this country has asked of teachers between March 2020 and August 2020. From March to May 2020, the nation's teachers immediately switched gears between in-person and remote instruction. Because of the urgency of the situation, the plans and types of instruction varied widely around the country, but it cannot go unnoticed that teachers remained responsible for student learning. In June and July of 2020, just as U.S. cases began to steadily increase (Centers for Disease Control, 2020), conversations began about reopening began: How could it be done, how many children might become ill or die, how many school days are required for in-person instruction, etc.? Teachers seemed missing from the conversation, but they were still tentatively hoping to interact with students again (Goldstein and Shapiro, 2020). Teachers' care for and about 
students remains; governmental assurances of teachers' safety does not.

COVID-19 has laid bare issues that have been present in teaching and teacher education for decades: the need to care, the emotions wrapped up in teachers' identities, and the frustration with small or significant interruptions to their important work. It is important to remember that it is nurturing, face-to-face interactions with the students that are so central to teachers' work, yet so risky during this pandemic. Danielewicz (2001) notes that teachers' sense of self is implicated by their enactment of reciprocal care (Noddings, 1992). For teachers, the "self is fully invested in teaching and caring" (Danielewicz, 2001, p. 165), and as teachers extend care to students, the students' acceptance of or response to that care matters greatly. PreCOVID-19, engaging in reciprocal care-based interactions with dozens to tens of dozens of students each day was incredibly demanding work that required teachers to maintain a sharp focus on students' reactions in order to interpret their concerns, needs, and engagement throughout the day. In turn, students' sense of being known impacts their own senses of self and efficacy. This is precisely why teachers dedicate the first several weeks of the year to establishing relationships, positive procedures, and methods of communication. Yet, when this intensive, responsive interaction is inhibited through virtual teaching or complicated by physical distancing and personal protective equipment (all while being hotly debated by community members and politicians), teachers' work and sense of self-worth are going to be challenged.

\section{CONCLUSION}

The point of this piece was to help readers understand the emotional complexity and issues of identity involved in truly relational teaching. The work great teachers do with students involves caring for and about them; responding to all sorts of academic, physical, and emotional needs; and designing instruction to meet frequently changing legislation and high-stakes assessments. The COVID-19 pandemic and the resulting conversations about education, both how teachers' work is incredibly hard (e.g., the March national narrative) and how dare they not get back to the classrooms so we can stimulate our economy (e.g., the June national narrative), have highlighted some of the public's misunderstandings about the work teachers actually do. Being asked to teach without Noddings (1984) confirming response and without the facets of the profession

\section{REFERENCES}

Akkerman, S. F., and Meijer, P. C. (2011). A dialogical approach to conceptualizing teacher identity. Teach. Teacher Educ. 27, 308-319. doi: $10.1016 /$ j.tate.2010.08.013

Alsup, J. (2006). Teacher Identity Discourses: Negotiating Personal and Professional Spaces. Routledge. doi: 10.4324/9781410617286

Ball, S. J. (2003). The teacher's soul and the terrors of performativity. J. Educ. Policy 18, 215-228. doi: 10.1080/0268093022000043065

Batarky, S. (1990) Femininity and Domination. New York, NY: Routledge. teachers align themselves with has created something of a crisis of identity.

These are difficult times for everyone. There are a number of notable authors and speakers who might suggest that every difficult situation is an opportunity for growth. An especially poignant quote:

Do you become discouraged easily, or do you bend to your advantage even the apparent ills of life? It is the difference between the pessimist and optimist: "The pessimist chews his quinine pills; the optimist, when chased up a tree by a bear, sits calmly and admires the view." Be an optimist; make reverses and rejections redound to your advantage (Holmes, 1915, p. 194).

The authors confess more than a bit of a discouraging attitude. While in March or April of 2020, we might have considered the immediate homeschooling taking place as a wake-up call to communities, "Oh, teaching is hard!" we are afraid we have returned to a place with which teachers are quite familiar: being asked to enact plans made by those with less experience and definitely fewer consequences, and to fix societal issues (e.g., the economy) they had nothing to do with breaking. As a PK-12 colleague said to one of the authors, it seems that the "Weight of all of this will fall on the shoulders of teachers, just like everything has up to this point."

Therefore, it is imperative that teachers, teacher educators, policymakers, and others advocate on behalf of teachers. Guidelines for reopening schools, for example, should weigh equally the concerns of teachers and community members. This work is hard but impactful on every level of society. Now, more than ever, we must be mindful of the outsized expectations that may be placed on teachers, and the resourcing necessary to support them. Anything less would undermine teacher emotions, agency, and identity, and their capacity to take action on behalf of their most beloved commitments. The professional knowledge, practical experience, and voices of teachers should not be discounted, lest teachers be left disregarded and disposable.

\section{AUTHOR CONTRIBUTIONS}

AJ and MK wrote the piece together. There were equal contributions with the theoretical framework and personal examples included. AJ developed most of the work on emotions and care, while MK developed and wrote most of the teacher identity sections. All authors contributed to the article and approved the submitted version.

Beauchamp, C., and Thomas, L. (2009). Understanding teacher identity: an overview of issues in the literature and implications for teacher education. Camb. J. Educ. 39, 175-189. doi: 10.1080/03057640902902252

Beijaard, D., Meijer, P. C., and Verloop, N. (2004). Reconsidering research on teachers' professional identity. Teach. Teacher Educ. 20, 107-128. doi: 10.1016/j.tate.2003.07.001

Britzman, D. P. (1993). The terrible problem of knowing thyself: toward a poststructuralist account of teacher identity, J. Curr. Theor. 9, 23-46.

Butler, J. (1999). Gender Trouble: Feminism and the Subversion of Identity. New York, NY: Routledge. 
Caine, V., Chung, S., Steeves, P., and Clandinin, D. J. (2020). The necessity of a relational ethics alongside noddings' ethics of care in narrative inquiry. Qual. Res. 20, 265-276. doi: 10.1177/1468794119851336

Centers for Disease Control (2020). Cases in the U.S. Available online at: https:/www.cdc.gov/coronavirus/2019-ncov/cases-updates/cases-in-us. html (accessed May 20, 2020).

Chiu, A. (2020). "I Wouldn't Trust you to Care for a House Plant": Democrats Blast DeVos for Insisting Schools Fully Reopen. Washington. Available online at: https://www.washingtonpost.com/ (accessed May 20, 2020).

Clandinin, D. J., and Connelly, F. M. (1996). Teachers' professional knowledge landscapes: teacher stories--stories of teachers--school stories--stories of schools. Educ. Res. 25, 24-30. doi: 10.3102/0013189X025003024

Clandinin, D. J., and Connelly, F. M. (1998). Stories to live by: narrative understandings of school reform. Curr. Inq. 28, 149-164. doi: 10.1111/0362-6784.00082

Connelly, F. M., and Clandinin, D. J. (eds.). (1999). Shaping a Professional Identity: Stories of Educational Practice. San Francisco, CA: The Althouse Press.

Craig, C. J. (2001). The relationships between and among teachers' narrative knowledge, communities of knowing, and school reform: a case of "The Monkey's Paw." Curr. Inq. 31, 303-331. doi: 10.1111/0362-6784.00199

Craig, C. J. (2002). A meta-level analysis of the conduit in lives lived and stories told. Teach. Teach. 8, 197-221. doi: 10.1080/13540600220127377

Cross Francis, D., Hong, J., Liu, J., and Eker, A. (2018). "I'm not just a math teacher": understanding the development of elementary teachers' mathematics teacher identity," in Research on Teacher Identity: Mapping Challenges and Innovations, eds P. A. Schutz, J. Hong, and D. C. Francis (New York, NY: Springer), 113-143. doi: 10.1007/978-3-319-93836-3_12

Danielewicz, J. (2001). Teaching Selves: Identity, Pedagogy, and Teacher Education. New York, NY: State University of New York Press.

Day, C., Elliot, B., and Kington, A. (2005). Reform, standards and teacher identity: challenges of sustaining commitment. Teach. Teach. Educ. 21, 563-577. doi: 10.1016/j.tate.2005.03.001

Edgington, U. (2016). Performativity and the power of shame: Lesson observations, emotional labour and professional habitus. Sociol. Res. 21, 136-150. doi: 10.5153/sro.3802

Foucault, M. (1979). Discipline and Punish. New York, NY: Vintage.

Fullan, M. (2007). The New Meaning of Educational Change. Routledge.

Goldstein, D., and Shapiro, E. (2020). 'I don't want to go back': Many teachers are fearful and angry over pressure to return. The New York Times. Available online at: https://www.nytimes.com/2020/07/11/us/virus-teachers-classrooms. html (accessed May 20, 2020).

Hamman, D., Gosselin, K., Romano, J., and Bunuan, R. (2010). Using possibleselves theory to understand the identity development of new teachers. Teach. Teach. Educ. 26, 1349-1361. doi: 10.1016/j.tate.2010.03.005

Haviland, J. M., and Kahlbaugh, P. (1993). "Emotion and identity," in Handbook of Emotions, eds, M. Lewis and J. M. Haviland (The Guilford Press), 327-339.

Holmes, W. S. (1915). "Cheer," in The Photoplay Author and Writer's Monthly (Springfield, MA: The Home Correspondence School), 194.

Izadinia, M. (2013). A review of research on student teachers' professional identity. Br. Educ. Res. J. 39, 694-713. doi: 10.1080/01411926.2012.679614

Jones, A. (2017). Relational Knowing and Responsive Instruction (Unpublished Doctoral Dissertation). University of Illinois at Urbana-Champaign.

Keck, C. S. (2019). The question teacher and the case for a therapeutic turn within teacher education. J Teach. Educ. 71, 1-11. doi: 10.1177/0022487119858982

Koestler, A. (1967). The Ghost in the Machine. Hutchinson.

Krasinski, J. (2020). Hamilton Cast Zoom Surprise: Some Good News With John Krasinski [Video]. Available online at: https://www.youtube.com/watch? $\mathrm{v}=$ oilZ1hNZPRM (accessed May 20, 2020).

Lortie, D. (1975). School Teacher: A Sociological Study. Chicago, IL: University of Chicago Press.

Lutovac, S. (2020). How failure shapes teacher identities: Pre-service elementary school and mathematics teachers' narrated possible selves. Teach. Teach. Educ. 94, 1-11. doi: 10.1016/j.tate.2020.103120

Meckler, L. (2020). Trump and DeVos Want Schools 'Fully' Open, but Not Many Are Listening. Washington. Available online at: https://www.washingtonpost.com/ (accessed May 20, 2020).

Milner, H. R. (2013). Policy Reforms and De-Professionalization of Teaching. National Education Policy Center. Available online at: http://nepc.colorado. edu/publication/policy-reforms-deprofessionalization (accessed May 20, 2020).
Mockler, N. (2011). Beyond 'what works': Understanding teacher identity as a practical and political tool. Teach. Teach. 17, 517-528. doi: 10.1080/13540602.2011.602059

National Education Association (NEA) (2019). NEA's Mission, Vision, and Values. Available online at: http://www.nea.org/home/19583.htm (accessed May 20, 2020).

Nias, J. (1996). Thinking about feeling: the emotions in teaching. Camb. J. Educ. 26, 293-306. doi: 10.1080/0305764960260301

Noddings, N. (1984). Caring: A Feminine Approach to Ethics and Moral Education. Berkeley, CA: University of California.

Noddings, N. (1992). In defense of caring. J. Clini. Ethics 3, 15-18.

Noddings, N. (2012). The caring relation in teaching. Oxf. Rev. Educ. 38, 771-781. doi: 10.1080/03054985.2012.745047

Noddings, N. (2013). Caring: A Relational Approach to Ethics \& Moral Education, 2nd Edn. Berkeley, CA: University of California. doi: 10.1525/97805209 57343

O'Connor, K. E. (2008). 'You choose to care': Teachers, emotions and professional identity. Teach. Teach. Educ. 24, 117-126. doi: 10.1016/j.tate.2006. 11.008

Rodgers, C., and Scott, C. (2008). "The development of the personal self and professional identity in learning to teach," in Handbook of Research on Teacher Education, eds M. Cochran-Smith, S. Feiman-Nemser, D. J. McIntyre, and K. E. Demers (New York, NY: Routledge), 732-755.

Ruohotie-Lyhty, M. (2018). Teacher identity and political construction. In: Research on teacher identity, eds P. Schutz, J. Hong, and D. Cross Francis (Springer), 25-36. doi: 10.1007/978-3-319-93836-3_3

Sawchuck, S., and Samuels, C. A. (2020). Where Are They? Students go Missing in Shift to Remote Classes. Education Week. Available online at: https://www.edweek.org/ew/articles/2020/04/10/where-are-they-studentsgo-missing-in.html (accessed May 20, 2020).

Strauss, V. (2020). A Veteran Teacher Has 'a Mini Covid-19 Educator Meltdown'and Realizes Less is More With Online Learning. Washington. Available online at: https://www.washingtonpost.com/education/2020/04/08/veteran-teacherhas-mini-covid-19-educator-meltdown-realizes-that-less-is-more-withonline-learning/ (accessed May 20, 2020).

Substance Abuse and Mental Health Services Administration. (2020). Intimate Partner Violence and Child Abuse Considerations During COVID-19. Available online at: https://www.samhsa.gov/sites/default/files/social-distancingdomestic-violence.pdf (accessed May 20, 2020).

Tyack, D. B., and Cuban, L. (1995). Tinkering Toward Utopia. Cambridge, MA: Harvard University Press.

Urzúa, A., and Vásquez, C. (2008). Reflection and professional identity in teachers' future-oriented discourse. Teach. Teach. Educ. 24, 1935-1946. doi: $10.1016 /$ j.tate.2008.04.008

Van Galen, J. A. (2017). Agency, shame, and identity: digital stories of teaching. Teach. Teach. Educ. 61, 84-93. doi: 10.1016/j.tate.2016. 09.009

Willen, L. (2020). Coronavirus Becomes Unprecedented Test for TeacherStudent Relationships. Hechinger Report. Available online at: https:// hechingerreport.org/coronavirus-becomes- unprecedented-test-for-teacherstudent-relationships/ (accessed May 20, 2020).

Winthrop, R. (2020). Top 10 Risks and Opportunities for Education in the Face of Covid-19. Brookings. Available online at: https://www.brookings.edu/blog/ education-plus-development/2020/04/10/top-10-risks-and-opportunitiesfor-education-in-the-face-of-covid-19/ (accessed May 20, 2020).

Zembylas, M. (2003). Interrogating "teacher identity": emotion, resistance, and self-formation. Educ. Theory 53, 107-127. doi: 10.1111/j.1741-5446.2003.00107.x

Conflict of Interest: The authors declare that the research was conducted in the absence of any commercial or financial relationships that could be construed as a potential conflict of interest.

Copyright (c) 2020 Jones and Kessler. This is an open-access article distributed under the terms of the Creative Commons Attribution License (CC BY). The use, distribution or reproduction in other forums is permitted, provided the original author(s) and the copyright owner(s) are credited and that the original publication in this journal is cited, in accordance with accepted academic practice. No use, distribution or reproduction is permitted which does not comply with these terms. 